811.112.2'373.611:811.163.41'373.611

821.112.2.08-38 Херндорф В. https://doi.org/10.18485/sj.2018.23.1.23

ДАНИЦА Б. НЕДЕЉКОВИЪ

Универзитет у Крагујевцу

Филолошко-уметнички факултет
Оригинални научни рад

Примљен: 04. 01. 2018.

Прихваћен: 29. 01. 2018.

\title{
ПРЕФИКСОИДИ КАО ОДЛИКА РАЗГОВОРНОГ ФУНКЦИОНАЛНОГ СТИЛА НА ПРИМЕРУ РОМАНА TSCHICK ВОЛФГАНГА ХЕРНДОРФА И ЮЕГОВОГ ПРЕВОДА НА СРПСКИ ЈЕЗИК
}

\begin{abstract}
У раду*** се анализирају творбене конструкције са елативним префиксоидима страног (латинског и грчког), а делом и немачког порекла, заступљене пре свега у разговорном функционалном стилу немачког језика, као и могућности постизања денотативне, конотативне и формалне еквиваленције приликом њиховог превођења на српски језик, у коме се наведени творбени образац сматра маргиналном појавом. У оба језика запажа се тенденција преласка везаних творбених морфема страног порекла из класе префикса у класу префиксоида као последица њиховог осамостаљивања у РФС, при чему је наведени процес код неких у потпуности окончан, док се код других јављају само назнаке самосталне употребе, карактеристичне за одређене подстилове РФС.
\end{abstract}

Кључне речи: префикс, префиксоид, разговорни функционални стил, немачки језик, српски језик, еквиваленција.

\footnotetext{
*dbmarjan@eunet.rs

*** Рад је урађен у оквиру пројекта 178014: Динамика структура савременог српског јези$\kappa a$, који финансира Министарство просвете, науке и технолошког развоја Републике Србије.

*** Један део рада изложен је у виду усменог саопштења на ХІ међународном научном скупу Српски језик, књижевност, уметност 29.10.2016. године на Филолошко-уметничком факултету Универзитета у Крагујевцу.
} 
1. Увод. Полазећи са једне стране од запажања да у немачком језику експлицитна деривација уз помоћ префиксоида домаћег и страног порекла у новије време представља веома продуктиван творбени образац, пре свега у разговорном функционалном стилу (РФС), те да префиксоиди фунгирају као носиоци конотативне (позитивне или негативне) семантике, а с друге стране од чињенице да у српском језику често не постоји формални еквивалент, овај рад има за циљ да на корпусном материјалу који чини роман Tschick Волфганга Херндорфа и његов превод на српски језик (Чик), испита инвентар префиксоида елативног значења у немачком и српском језику, њихову дистрибуцију и стилску маркираност, као и лексичка средства којима је у српском језику, услед непостојања формалног еквивалента, могуће постићи конотативну и денотативну еквиваленцију ${ }^{1}$.

Сходно томе, метода која се у раду примењује је контрастивна анализа, и то једносмерно, са немачким као полазним, а српским као циљним језиком.

Анализа ће показати да је инвентар префиксоида у српском језику већи него што је то до сада у литератури запажено и да се може објаснити тенденцијом осамостаљивања елативних префикса страног (латинског и грчког) порекла, одн. њиховом конверзијом у класу (нефлектираних) придева и прилога, те постојањем хомонимних форми, што се пре свега запажа у језику младих (као подстилу РФС), а за резултат има и промену статуса датих везаних морфема, које из класе префикса прелазе у класу (елативних) префиксоида. У ову групу спадају super-, extra- и mega- у немачком, одн. cynep-, екстра- и мега- у српском језику. Како, међутим, наведени процес ни у немачком ни у српском језику није код свих представника у потпуности окончан, могући су и гранични случајеви, нпр. ultra- / ултра- и giga- / гuгa-, док елативни префикс hyper- / xunеp- за сада не показује тенденцију ка осамостаљавању.

2. Корпус. Деривати са префиксоидом као творбеним елементом имају наглашену експресивну вредност, те су заступљени пре свега у РФС, који се налази на граници између стандарда и супстандарда, а карактерише га „незванични, неусиљени, спонтани, претежно усмени и дијалошки начин изражавања" (Тошовић 2002: 309; 321). Иако је његов примарни појавни облик усмени вид комуникације (тзв. природни РФС), он је заступљен и као сегмент других стилова, најчешће књижевноуметничког (КФС), као стилизовани (обрађени, рефлектовани, одсликани) РФС (исто, 312), што је случај и у роману Tschick (Чик), који чини наш корпус.

Жанровски, овај роман би се могао одредити као роман за младе, иако није објављен као такав, а говори о пријатељству двојице 14-годишњака, од

\footnotetext{
${ }^{1}$ Детаљније о типовима еквиваленције в. Колер (2011: 219; 230-269). Аутор разликује денотативну, конотативну, текстуално-нормативну, прагматичну и формално-естетску еквиваленцију, од којих су за наше истраживање релевантне формална, денотативна и конотативна.
} 
којих један, Мајк Клингенберг, потиче из добростојеће грађанске породице, у којој су, међутим, односи нарушени, а он потпуно запостављен, а други, Чик, тј. Андреј Чихачов, је досељеник из Русије и потиче из веома лошег социјалног миљеа. Радња се дешава у Берлину, за време летњег распуста, када њих двојица крећу украденом старом ладом у авантуру без мапе и компаса (и без возачке дозволе) кроз њима непознате пределе Источне Немачке, са идејом да стигну у Влашку, за коју не знају тачно ни где је ни да ли уопште постоји.

Наратор је дечак Мајк Клингенберг, који у првом лицу препричава њихове авантуре. Увођењем приповедача у текст (тзв. Ја-Форма) омогућава се „очување свих карактеристичних језичких особина које тај лик смештају у неку средину, у одређено доба, социјалну групу или слично", док је ауторски говор сведен на нулу (Катнић-Бакаршић 1999: 38-39). Волфганг Херндорф веома успешно успева да се стави у позицију главних јунака и да из перспективе приповедача крајње аутентично конструише језик (жаргон) младих, са мноштвом колоквијализама, жаргонизама, англицизама, а често и вулгаризама.

Отуда се као стилска доминанта романа издваја емоционално-експресивна лексика, којој статус лексикостилема обезбеђује управо велика творбена креативност. Посебно место при том заузимају експилицитни деривати са префиксоидом као творбеном морфемом у функцији семантичке модификације основе (придева или именице), којим се маркира диференцијална сема 'степен, интензитет', а настала творбена конструкција постаје стилски маркирана и припада разговорном стилском слоју или неком још нижем супстандарду (Петронијевић 2005).

3. СТАТУС АФИКСОИДА У ЛИТЕРАТУРИ. Пре Него ШТо ПредставИМо резУЛтате анализе, неопходно је најпре укратко дефинисати префиксоиде (нем. das Präfixoid), који заједно са суфиксоидима спадају у класу афиксоида (нем. das Affixoid, das Halbaffix), творбених, дакле везаних морфема, које у морфематском систему немачког језика заузимају посебно место, будући да се формално подударају са основичким морфемама, али не и семантички, јер је њихово значење уопштеније, апстрактније од хомоформног пандана. Уз то, афиксоиди имају фиксну позицију, творе низове и не могу се комбиновати са афиксима (Елзен 2009: 326). Важно је, међутим, напоменути да је статус афиксоида у германистичкој дериватологији, посебно новијој, споран, те да многи аутори, наслањајући се на аргументе које је о афиксоидима изнео Г. Д. Шмит (1987), одустају од ове међукласе морфема у корист основичких с једне, и творбених (афикса) с друге стране (нпр. Флајшер и Барц 1995: 27-28, Доналис 2005: 25-26, Алтман и Кемерлинг 2000: 53; 102; Моч 1999: 283; 367-370; Ајзенберг 2006: 218 и др.), док други и даље сматрају њихово издвајање у посебну класу морфема оправданим (нпр. Елзен 2009: 326; 2011: 29-30; Ремер 2006: 198; Сатмари 2011: 164; Петронијевић 2005 и др.), што 
за резултат има различите интерпретације истих творбених конструкција ${ }^{2}$. Међутим, и поред неусаглашених ставова, запажамо да сви наведени аутори указују на специфичности ових морфема, будући да афиксоиди немају типичне карактеристике ни творбених ни основичких морфема, или су оне присутне само у ослабљеној форми (Сатмари 2011: 157).

Са друге стране, србистичка дериватологија (нпр. Клајн 2002 (1): 140-165; Станојчић и Поповић 2004: 136; Һорић 2008: 119-124; ПСЈ 2011: 77-81) у класу афиксоида највећим делом сврстава основичке морфеме грчког и латинског порекла, које се не могу јављати самостално, већ само као једна конституента сложенице (нпр. био-, гео-, хидро-, тео- одн. -тека, -фил, -логија и сл.), дакле оне морфеме које германистичка лингвистика дефинише као конфиксе (das Konfix $)^{3}$, док творбене морфеме које представљају предмет нашег истраживања (супер-, екстра-, мега-, ултра- и гига-) веома често дефинише као префиксе страног порекла.

Када је реч о контрастивним истраживањима, у постојећим контрастивним граматикама за језички пар немачки-српски појму афиксоид приступа се са германистичког становишта, али се они обрађују заједно са афиксима, без детаљније анализе и указивања на припадност конкретног елемента једној или другој групи творбених морфема (Алановић и др. 2014: 26-42; 103-107), док се у старијој контрастивној граматици (Енгел и Мразовић 1986 (I): 331-332; 384-388) префиксоидима уопште не придаје значај, а суфиксоиди спомињу само у творби адјектива немачког језика, обухватајући највећим делом заправо придевске сложенице.

Од контрастивних истраживања посебно се издваја рад Б. Петронијевић (2005), где се јасно указује на особине и статус афиксоида у немачком, као и на назнаке овог процеса у српском језику. Афиксоиди се дефинишу као морфеме које имају облик основичких, али спадају у класу везаних морфема и творе низове, при чему долази до семантичког одступања у односу на хомонимну

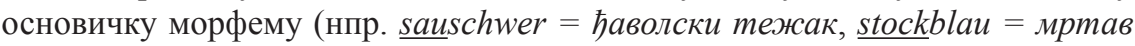
nијан; Astwerk $=$ крошьа, грање; Mänпеrvolk $=$ мушкарии, мушкадија), што, као што примери показују, за резултат има немогућност њиховог јављања у парафрази. Афиксоиди, даље, искључују могућност да у непромењеном значењу фунгирају као хипероним сложеница или као основа експлицитних деривата. Аутор наглашава да је ова појава далеко присутнија и продуктивнија у немачком језику, док српски готово да не познаје афиксоиде, пре свега суфиксоиде, док се од префиксоида издваја морфема супер, али не у свим реализацијама, већ само тамо где долази до померања значења у односу на

\footnotetext{
${ }^{2} \mathrm{O}$ различитим интерпретацијама датих твореница, као и о аргументима за и против афиксоида као посебне класе морфема в. Сатмари (2011), Елзен (2009) и др.

${ }^{3}$ О разлици између конфикса и афиксоида в. Елзен (2005; 2011: 31-32).
} 
основичку морфему (уп. супербогат $\rightarrow$ веома богат (префиксоид) vs. суперручак $\rightarrow$ ручак је супер (придев)), те је и овде присутна хомонимија.

Полазећи од наведених теоријских поставки, у раду ћемо се детаљније бавити елативним префиксоидима страног порекла у немачком и српском језику.

4. ПРЕФИКСОИДИ СТРАНОГ ПОРЕКЛА. У корПУСУ НемачкоГ језИКа Потврђени су следећи префиксоиди страног порекла: super-, extra- и mega-, који у српском језику имају формалне еквиваленте (кореспонденте): супер-, екстра- и мега-. Напоменули смо већ да се у германистичкој литератури обично говори о елативним префиксима грчког и латинског порекла (super- и extra-), или о префиксоидима тј. конфиксима (extra- и mega-), уз запажање да неки од њих, пре свега super и extra фунгирају и као основичке морфеме - нефлектирани придеви и прилози (Доналис 2005: 28; Флајшер и Барц 1995: 121; Моч 1999: 369 и др.), док се теga- не издваја као самостална (основичка) морфема. Као аргумент због чега се и поред постојања слободног пандана морфема super и даље интерпретира као префикс, у литератури се обично наводи чињеница да је она у немачки језик најпре ушла као префикс којим се изражава категорија степена, да би се тек накнадно (70-тих година прошлог века) осамосталила у значењу „изврсно” (Елзен 2011: 304). Занемарује се при том чињеница да, са синхроног аспекта, наведени елемент показује све особине префиксоида ${ }^{5}$. Са друге стране, морфеме hyper- / хипер- и ultra- / ултра-, које се у литератури (према семантичком критеријуму) обично наводе заједно са горе поменутима, још увек нису прешле пут од префикса до слободне морфеме (мада код ultra- / ултра- и giga- / гига- постоје назнаке ове тенденције у говору младих), те се са разлогом сврставају у елативне префиксе.

4.1. ПРЕФИКСОИДИ SUPER-/СУПЕР- И ЕХTRA-/ЕКСТРА-. Оба ПрефИКсоИДа СУ латинског порекла (lateinisch super = oben, (dar)über; über - hinaus; lateinisch extra $=$ außerhalb, außerdem; über ... hinaus; Дуден 2006) и врше функцију семантичке модификације придева или именице, остварујући се при том у следећим творбеним обрасцима:

a) super- / cynep- одн. extra- / екстра- + придев ('степен, интензитет')

б) super- / cynep- + именица ('главни (Х) у односу на $\mathrm{Y}^{\prime}$ )

${ }^{4}, \ldots$ super ist als Präfix zur Steigerung ins Deutsche gekommen. Erst nachträglich verbreitete es sich in der Bedeutung 'hervorragend'. Als freies Lexem tritt es seit Anfang der 70er Jahre auf (...)." (Елзен 2011: 30)

${ }^{5}$ Када је реч о морфеми супер, поред чињенице да једна морфема „не може истовремено бити и префикс и слободна морфема", као додатни аргумент у прилог њеној класификацији у префиксоиде наводи се и чињеница да слободна морфема супер у међувремену фунгира и као база експлицитног деривата супериика (Петронијевић 2005). 
4.1.1. Уколико врши семантичку модификацију придева, префиксоид super- / cynep- означава екстремни / највиши степен одн. интензитет особине изражене датим придевом (супербогат) и има емоционално наглашену, најчешће позитивну конотацију (Моч 1999: 282-3). Како примери из нашег корпуса показују, ово значење је доминантно. Ради илустрације навешћемо неке од примера ${ }^{6}$ :

\begin{tabular}{|c|c|}
\hline $\begin{array}{l}\text { 1) Der kommt rein wie eine Maschine und } \\
\text { fängt an zu reden, und dann geht es } 45 \\
\text { Minuten superkorrekt zu, und dann geht } \\
\text { Kaltwasser wieder raus, und man weiß } \\
\text { nicht, was man davon halten soll. (53) }\end{array}$ & $\begin{array}{l}\text { 'Ulazi u odeljenje kao mašina i počinje da } \\
\text { priča, pa onda četrdeset pet minuta protekne } \\
\text { superkorektno, a na kraju Kaltvaser izađe i } \\
\text { ne znate šta da mislite o tome. (55) }\end{array}$ \\
\hline $\begin{array}{l}\text { 2) Ich sah mich schon immer mit ihm in } \\
\text { seinem Wohnzimmer am Kamin stehen } \\
\text { und supergepflegt Konversation machen. } \\
(57-8)\end{array}$ & $\begin{array}{l}\text { 'Već sam video sebe kako stojim sa njim u } \\
\text { dnevnoj sobi kraj kamina i vodim superotme- } \\
n u \text { konverzaciju. (59) }\end{array}$ \\
\hline $\begin{array}{l}\text { 3) ..., weil ich beim Zeichnen an nichts } \\
\text { anderes mehr denken konnte als an Tat- } \\
\text { jana und ihren Geburtstag und ihren } s u \text { - } \\
\text { persympathischen Onkel, mit dem ich am } \\
\text { Kamin unfassbar geistreiche Gespräche } \\
\text { führte. (59) }\end{array}$ & $\begin{array}{l}\text { '..., jer crtajući nisam mogao da razmišljam ni } \\
\text { o čemu drugom, nego samo o Tatjani i njenom } \\
\text { rodjendanu i njenom supersimpatičnom ujaku } \\
\text { sa kojim za kaminom vodim strava pametne } \\
\text { razgovore. }(60)\end{array}$ \\
\hline $\begin{array}{l}\text { 4) Die Schwestern sind alle superjung und } \\
\text { superfreundlich. (15) }\end{array}$ & $\begin{array}{l}\text { 'Sve odreda su skroz mlade i superljubazne. } \\
\text { (17) }\end{array}$ \\
\hline
\end{tabular}

Поређењем оригинала и превода запажа се да је код овог творбеног обрасца могуће постићи формалну, денотативну и конотативну еквиваленцију, при чему префиксоид super- / cynep- изражава екстремни степен особине придева као основичке морфеме. Експлицитну потврду за дату тврдњу налазимо у примеру 4), где се као преводни еквивалент прве творбене конструкције (ТК) јавља придевска фраза са градуативном партикулом „скроз”, те у датом случају изостаје формална еквиваленција (superjung - скроз млад), премда такав еквивалент постоји (superjung - супермлад), док је у случају друге ТК постигнута апсолутна еквиваленција (superfreundlich - суперљубазан).

Са друге стране, као еквивалент немачког префиксоида super- у српском језику може се јавити и морфема екстра-, што потврђују следећи примери:

\footnotetext{
${ }^{6}$ У раду се примери у оригиналу означавају бројевима и наводе у левој колони, а њихови преводи симболом ' у десној колони. Након примера, у загради се наводи страница на којој је наведени пример потврђен у корпусу.
} 
5) Da klingelt man nachts um vier irgendwen aus dem Bett, weil man gar nichts von ihm will, und er ist superfreundlich und bietet auch noch seine Hilfe an. (209)

6) Es war kein superkomplizierter Text, es waren sogar nur neun Worte, aber ich musste sie trotzdem fünfmal lesen, um sie zu verstehen. (238)

7) ..., und ich musste mir noch irgendwelche Ausreden für ihn ausdenken und erklären, dass alles superokey war hier. Was es ja auch war. (100)
'Tako smo usred noći, u četiri, digli nekoga iz kreveta i nećemo od njega ništa, a on je ekstra ljubazan i još nudi pomoć. (209)

'Tekst nije bio nešto ekstra komplikovan, samo osam reči, ali sam ipak morao da ih pročitam pet puta da bih razumeo. (237)

'..., pa sam morao da smislim još nekoliko izgovora i da mu objasnim da je ovde sve ekstra okej. Što i jeste bilo. (100)

Запажа се да је у примерима 5), 6) и 7) постигнута денотативна и конотативна еквиваленција, али не и формална, будући да екстра услед одвојеног писања фунгира као градуативна допуна придева, нуклеуса фразе (нпр. superfreundlich vs. екстра љубазан). О формалној еквиваленцији могло би се говорити у случају састављеног писања, које правописна норма српског језика у значењу 'степен, интензитет' заправо и налаже (ПСЈ 2011: 80: екстрапоnуларан, екстрасубјективан и сл.), као што би то и у немачком језику требало увек да буде случај (Дуден 2006: extraklug, extralang, extradumm), мада у корпусу немачког језика једини потврђени пример са морфемом extra показује супротно - раздвојено писање у односу на основичку морфему:

8) Da gingen wir extra langsam zum Lada zurück. (162)
'Onda smo se sasvim lagano vratili do lade. (161)

Ипак, у свим наведеним примерима како немачког тако и српског језика, морфема extra / екстра употребљена је у значењу префиксоида ('степен, интензитет'), а не хомонимног придева / прилога, који је у конотативној, дакле стилски маркираној употреби (пре свега у РФС) семантички подударан са придевом одн. прилогом super (нпр. Das war extra! / To је било екстра!), мада још интензивније него супер наглашава стилску маркираност и припадност РФС, пре свега језику младих ${ }^{7}$. Упореди:

\footnotetext{
${ }^{7}$ Будући да је реч о полисемном придеву одн. прилогу extra / екстра, наведену, стилски маркирану лексему екстра (као синоним лексеме супер) треба разликовати од стилски немаркиране лексеме екстра, која има значење 'додатни' и фунгира као детерминативна конституента сложеница (нпр. Extrabonus, Extraurlaub, Extravorstellung / екстразарада, екстрапрофит) или самостално (нпр. etwas extra bezahlen одн. плаћа се екстра) (Дуден 2006; ПСЈ 2011).
} 
9) ..., und da kann man sagen, was man will, die Pampe schmeckte phantastisch. (130)

10) Danach ging es mir wieder blendend, und ich hatte nichts dagegen, noch stundenlang weiter zu laufen auf der Suche nach einem Schlauch. (149)
'Možemo da kažemo šta hoćemo, ali bućkuriš je bio ekstra. (130)

'Posle toga sam se opet osećao ekstra, nisam imao više ništa protiv da hodamo još satima u potrazi za crevom. (148)

Самостална употреба лексеме extra / екстра у наведеном, стилски маркираном значењу далеко је чешће забележена у корпусу српског језика, што потврђују и примери 9) и 10), док су у немачком обично заступљени елативни придеви разговорног / колоквијалног регистра (нпр. phantastisch, blendend и сл.). Разлог томе могла би бити чињеница да се, према Дуденовом речнику (2006), лексема extra у значењу „сјајно, одлично, изврсно” употребљава само регионално (landschaftlich).

Са друге стране, префиксоиди super- / cynep- одн. extra- / екстра- су у свим контекстима међусобно заменљиви.

4.1.2. Уколико врши семантичку модификацију именице, префиксоид super-/ cynep- остварује се у значењу 'главни (X) у односу на Ү' (нпр. суnервизор, суперсила, Петронијевић 2006), те можемо да закључимо да је у питању полисемни префиксоид, који са слободном морфемом супер стоји у односу хомонимије. Као потврду за ово у нашем копрусу налазимо само један пример у немачком језику (Superstar), који у српском није преведен истим творбеним обрасцем, иако формални еквивалент (кореспондент) постоји (суперзвезда):

11) Dir nie aufgefallen? Tatjana Superstar. (85)

'Nisi je snimio? Tatjana glavna faca. (85) $\rightarrow$ суперзвезда

За разлику од префиксоида super- / cynep-, који се јавља и у примерима Superfrau, Supergau, Superwahljahr и др. у немачком, одн. супержена, суперсила, супердржава, суперхерој и др. у српском језику, префиксоид ехtra- / екстра- се не остварује у наведеном значењу и наведеном творбеном обрасцу, те не може бити речи о полисемном префиксоиду.

Са друге стране, супер и екстра су међусобно заменљиви када се јаве као лексичка (основичка) морфема, било као детерминативна конституента детерминативне сложенице $\left(12,13^{\prime}\right)$ или као атрибут уз именицу (14'). Упореди: 


\begin{tabular}{|c|c|}
\hline $\begin{array}{l}\text { 12) ..., und das wäre ein „Superjob” und sie } \\
\text { wäre ,,voll überqualifiziert” ... (156) } \rightarrow \text { Der } \\
\text { Job ist super. }\end{array}$ & $\begin{array}{l}\text { '... i to je bio ,ekstraposao", a ona je ,skroz } \\
\text { prekvalifikovana” za to, ... (156) } \rightarrow \text { Посао } \\
\text { je eкстра. }\end{array}$ \\
\hline $\begin{array}{l}\text { 13) Ich schwöre, dass ich noch nie so geilen } \\
\text { Schaum mit Himbeeren darauf gegessen } \\
\text { hab. (132) }\end{array}$ & $\begin{array}{l}\text { 'Kunem se da nikad nisam jeo takvu } \\
\text { ekstrapenu sa malinama. (132) } \rightarrow \text { Пена } \\
\text { je eкстра. }\end{array}$ \\
\hline 14) Tolle Figur, aber voll asi." (159) & $\begin{array}{l}\text { 'Ekstra telo, ali potpuno asocijalan lik.' } \\
(157) \rightarrow \text { Тело је екстра. }\end{array}$ \\
\hline
\end{tabular}

Да је реч о основичкој, а не о творбеној морфеми (префиксоиду), потврђује могућност парафразе, у којој наведене морфеме остварују своје основно значење и фунгирају као предикатив уз копулативни глагол. Наведени примери такође потврђују већ изнесену тврдњу да се лексема extra / екстра у самосталној употреби у РФС далеко чешће користи у српском него у немачком језику, као еквивалент стилски маркираних придева елативног значења (овде: geil и toll).

Остаје проблем састављеног и растављеног писања у српском језику. Наиме, у примерима 12') и 13') јавља се детерминативна сложеница, а у 14') именичка фраза са нефлектираним придевом као сателитом, док је трансформација у сва три случаја иста. Према ПМС (2011: 80), одвојеним писањем наглашава се квалификација, што се показује и засебним акцентом (екстра услови, екстра укус, супер журка).

4.1.3. На крају овог поглавља можемо да изведемо закључак да оба префиксоида, и super- / cynep- и extra- / екстра-, имају афективно и елативно значење, емоционално и експресивно су маркирани, као и да су у творбеном обрасцу префиксоид + придев, са значењем 'крајњи степен, интензитет' међусобно заменљиви као апсолутни синоними, док се у творбеном обрасцу префиксоид + именица, који остварује значење 'главни (X) у осносу на $\mathrm{Y}$ ', јавља само префиксоид super- / cynep-. Да су у питању префиксоиди, а не префикси, потврђују бројни примери њихове самосталне реализације у виду основичке морфеме с једне стране, као и одступање од датог значења у ТК ове врсте с друге стране.

4.2. ПРЕФикСоИд MEGA-/МЕГА-. У блиској семантичкој вези са префиксоидима super-/ cynep- и extra- / екстра- стоји и префиксоид теga- /мега-, такође страног порекла (griechisch mégas = groß, уп. Дуден 2006) и елативног значења. Иако се у литератури (како германистичкој, тако и србистичкој) мега- дефинише као префикс (Доналис 2005: 26, 97, 107; Моч 1999: 369) или сврстава у граничне случајеве (Клајн 2002: 147) одн. обрађује као страни препозитивни елемент (Ћорић 2008: 137-8), новије тенденције у разговорном савременом 
немачком и српском језику показују да је присутна вишеструка хомонимија, те да теga- / мега- фунгира као:

а) конфикс, када се реализује као мерна јединица, у значењу 'милион'8 (нпр. Megavolt, Megatonnе одн. мегаволт, мегатона и др.);

б) префиксоид, у значењу 'степен, интензитет', као синоним префиксоида cynер- и екстра- (нпр. megacool, megamodern одн. мегакул, мегамодерно и др.). Класификација морфеме теga- / мега- у префиксоиде, а не у префиксе, оправдава се његовом све чешћом самосталном употребом у РФС савременог немачког и српског језика (в. под в));

в) придев или прилог елативног значења (у истом значењу као и супер и екстра), што потврђује и одредница у Дуденовом речнику (2006), који теgaс једне стране дефинише као префикс грчког порекла (у нашој интерпретацији префиксоид) карактеристичан за РФС, где има наглашено емотивно и експресивно значење (megacool, megastark), а са друге као недеклинирани придев, који се, посебно у говору младих, употребљава у значењу „изврстан, фантастичан" (großartig, hervorragend), као у примеру: das war einfach mega. Потврде за то налазимо у језику младих, у писаним електронским медијима (пре свега форумима), о чему сведоче следећи примери (преузети из интернет извора), у којима мега увек фунгира као нефлектирани придев, док у српском може да се реализује и као прилог (в. пример 17a):

\begin{tabular}{|l|l|}
\hline $\begin{array}{l}\text { 15) Lake Festival war einfach MEGA! } \\
\text { (https://zh-cn.facebook.com; 20.4.2017.) }\end{array}$ & $\begin{array}{l}\text { 15a') „Ovde je baš MEGA!”, uzvikne } \\
\text { lepa plavuša, dok joj širok osmeh } \\
\text { blista na licu. }\end{array}$ \\
\hline $\begin{array}{l}\text { 16) Mega Stimmung super Djs!!! } \\
\text { (http://www.oeticket.com; 20.4.2017.) }\end{array}$ & $\begin{array}{l}\text { 16a),Bilo nam je mega, mega” (Фолк } \\
\text { песма) }\end{array}$ \\
\hline $\begin{array}{l}\text { 17) Die hügelige, bewaldete Umgebung ge- } \\
\text { fiel mir mega. (https://www.yumpu.com/de/ } \\
\text { document; 20.4.2017.) }\end{array}$ & $\begin{array}{l}\text { 17a) Mega } \text { smo se ložili na to. (https:// } \\
\text { www.vice.com/rs/article; 20.4.2017) }\end{array}$ \\
\hline
\end{tabular}

Међутим, у корпусу немачког језика потврђен је само један пример у коме префиксоид теga- семантички модификује нефлектирани придев колоквијалног стила, при чему у српском језику није реализован исти творбени модел (а могао је бити), те је остварена само денотативна и конотативна еквиваленција. Упореди:

\footnotetext{
${ }^{8}$ Mega- [griech. mégas = groß]: bedeutet in Maßeinheiten eine Million: Megavolt. (Дуден 2006)

${ }^{9}$ Словом а) поред броја означавамо да није у питању превод, већ је пример преузет из интернет корпуса српског језика.
} 
18) „Wenn die uns nachläuft, ist megakacke”, sagt Tschick. (158)

„Ako bude išla za nama, biće gadno sranje", rekao je Čik. (157) $\rightarrow$ мегасрање

Са друге стране, наш корпусни материјал показује да је употреба префиксоида мега- у српском језику далеко чешћа у односу на немачки, и јавља се као апсолутни (формални, денотативни и конотативни) преводни еквивалент немачких (деноминалних) префиксоида end- и riesen-, те можемо да успоставимо однос више vs. један: mega- / end- / riesen- vs. мега-. Бројни су примери таквих ТК у нашем корпусу, при чему префиксоид end- семантички модификује искључиво придев, а riesen- обично именицу, док mega- / мега- нема дистрибутивних ограничења ни у немачком ни у српском језику и остварује се у следећим творбеним обрасцима (Дуден $2006^{10}$ ):

a) mega- / мега- + придев ('степен, интензитет'): megacool, megastark / мегапаметан

б) теgа- / мега- + именица ('главни (X) у односу на $\left.\mathrm{Y}^{\prime}\right)$ - изражава још већи степен / интензитет у односу на префиксоид super-/ cynep-: Megaprojekt, Megatrend / мегатренд.

У делу који следи анализираћемо префиксоиде немачког порекла, који у српском за еквивалент имају префиксоид мега-, а то су у нашем корпусу end- и riesen-.

4.2.1. Префиксоид end- спада у ону групу префиксоида код којих је семантичка веза са хомонимном слободном морфемом (das Ende) прозирна. Ипак, значење префиксоида end- разликује се у односу на хомонимну слободну морфему - оно је апстрактније, општије, те попут осталих елативних префиксоида исказује 'екстремни степен, интензитет' особине изражене придевом (нпр. endklug, enddumm и сл.), што је уједно и једини творбени образац у којем се овај префиксоид остварује. Наиме, уколико модификује именицу, End- фунгира као основичка морфема, тј. детерминативна конституента у детерминативној сложеници (нпр.: Endbetrag, Endeffekt, Endkampf и др. $\left.{ }^{11}\right)$. Увидом у доступну нам литературу запажамо да end- у германистичкој дериватологији није препознат као префиксоид (Доналис 2005, Алановић и др. 2014, Флајшер и Барц 1995, Алтман и Кемерлинг 2000, Моч 1999 и др.),

${ }^{10}$ mega-, Mega: 1. drückt in Bildungen mit Adjektiven eine Verstärkung aus; sehr, äußerst; Gebrauch: (umgangssprachlich emotional verstärkend); Beispiel: megacool, -stark; 2. kennzeichnet in Bildungen mit Substantiven jemanden oder etwas als besonders groß, mächtig, hervorragend, bedeutend (als Steigerung von Super-), Gebrauch: emotional verstärkend, Beispiel: Megaprojekt, -trend (Дуден 2006).

${ }^{11}$ End-: drückt in Bildungen mit Substantiven aus, dass etw. - seltener jmd. - den endgültigen Schlusspunkt nach mehreren Zwischenstationen darstellt: Enddeponie, Endmontage (Дуден 2006, одредница End-). 
вероватно услед узимања у обзир само творбеног обрасца са именицом као основичком конституентом.

Како примери из нашег корпуса показују, формална еквиваленција се у српском језику остварује помоћу префиксоида мега-, као у примеру 19), док је у примеру 20) постигнута денотативна и конотативна еквиваленција, али су заступљени различити творбени обрасци: у немачком је творбена основа придев, а у српском именица, што је последица ограничења у дистрибуцији префиксоида end- (семантички модификује искључиво придев) у односу на префиксоид мега-, који, као што смо већ напоменули, ни у немачком ни у српском језику не показује дистрибутивна ограничења. Отуда би се као апсолутни еквивалент у немачком језику могао реализовати дериват Megaidiot или Riesenidiot, будући да се префиксоид riesen- најчешће комбинује са именицом (в. 4.2.2.). Упореди:

19) Paul war mein Freund seit dem Kindergarten, und wir haben uns fast jeden Tag getroffen, bis seine endbescheuerte Mutter beschlossen hat, dass sie lieber im Grünen wohnen will. (21)

20) Aber Strahl war eben Mathelehrer und endgestört. (50) $\rightarrow$ Megaidiot
'Paul je moj prijatelj još iz obdaništa i viđali smo se svakog dana, dok njegova megaćaknuta mama nije poželela da živi u prirodi. (23)

'Ali Štral je bio profesor matematike i megakreten. (52)

У примерима који следе није остварена коресподенција, будући да је значење префиксоида 'екстемна вредност' изражено атрибутом уз именицу (21), одн. градуативом допуном уз придев (22), чиме се потврђује теза о префиксоидном статусу морфеме end-. Упореди:

\begin{tabular}{|l|l|}
\hline $\begin{array}{l}\text { 21) ..., und ich hörte mir das sehr genau an, weil } \\
\text { mir schien, dass dieser Richter nicht gerade } \\
\text { endbescheuert war. (236) }\end{array}$ & $\begin{array}{l}\text { '.., pa sam to pažljivo slušao jer mi } \\
\text { se cinilo da taj sudija nije baš totalna } \\
\text { budala. (235) }\end{array}$ \\
\hline $\begin{array}{l}\text { 22) Aber diese Zeichnungen waren nicht toll, } \\
\text { die waren einfach nur endbescheuert,... (22) }\end{array}$ & $\begin{array}{l}\text { 'Ali ovi crteži nisu bili sjajni, nego } \\
\text { potpuno otkačeni, ... (24) }\end{array}$ \\
\hline
\end{tabular}

Напоменимо на крају још и то да, и поред чињенице да префиксоид end- у свим примерима из нашег корпуса семантички модификује негативно конотиране основичке морфеме, он не искључује ни реализације са придевима који имају позитивно значење (нпр. endschön, endinteressant).

4.2.2. Између аугментативног префиксоида riesen-, којим се остварује значење 'изразито велики степен, интензитет' (Riesenkrach, Riesenapplaus) и његовог хомонима, именице Riese (= џин (лик из бајке); изразито висока особа / ствар), семантичка веза је прозирна, а настала је директним поређењем. 
Парафраза, међутим, није могућа (нпр. Riesenkrach $\neq$ Krach eines Riesen), мада се ТК са префиксоидом riesen- у творбеном обрасцу префиксоид + именица обично може трансформисати у семантички еквивалентну фразу са деноминалним придевом riesig као сателитом: Riesenkrach = riesiger Krach (Флајшер и Барц 1995: 27; 100; 231), при чему се полисемни префиксоид riesen- остваpyје у четири значењске варијанте - екстремно велики: обим (Riesenhaus); број, количина, размера (Riesenauswahl); интензитет (Riesendurst); квалитет (Riesenspiel) (ДУДеН 2006 ${ }^{12}$ ). СА ДРУГЕ СТРАНЕ, ТВОРБЕНИ ОБРАЗАЦ ПРЕФИКСОИД + АДЈЕКТИВ МАњЕ ЈЕ ФРЕКВЕНТАН У ОДНОСУ НА ПРЕТХОДНИ, А ТК ОВОГ ТИПА ОБИЧНО СУ ЛЕКСИКАЛИЗОВАНЕ И ОСТВАРУЈУ ЈЕДИНО ЗНАЧЕњЕ 'ЕКСТРЕМНО ВЕЛИКИ СТЕПЕН, ИНТЕНउИTET' (HIP. RIESENGROSS, RIESENSTARK = BESONDERS GROSS, BESONDERS STARK).

У нашем корпусу потврђен је само један придевски дериват:

(23) Nach vier Wochen harter Arbeit sah Beyonce fast wie ein Foto aus, eine riesengroße Bleistiftbeyonce mit Tatjanas Augen, ... (60)
'Posle četiri nedelje naprnog rada Bijonse je izgledala gotovo kao fotografija, džinovska olovkom nacrtana Bijonse sa Tatjaninim očima, ... (61)

Са друге стране, бројни су деривати са именицом као творбеном основом, при чему полисемни префиксоид riesen- маркира изразито велики интензитет $(24,25)$ одн. обим појма израженог именицом (26). Као апсолутни (формални, денотативни и конотативни) еквивалент у српском језику јавља се ТК са префиксоидом мега-. Упореди:

\begin{tabular}{|l|l|}
\hline $\begin{array}{l}\text { 24) Aber es war ein Riesengestank, der von } \\
\text { ihr ausging. (156) }\end{array}$ & 'Ali ona je širila megasmrad. (155) \\
\hline $\begin{array}{l}\text { 25) Der älteste Sohn winkte mir mit der Grill- } \\
\text { zange zu, und weil er ein Riesenarschloch ist } \\
\text { wie alle unseren Nachbarn, guckte ich schnell }\end{array}$ & $\begin{array}{l}\text { 'Najstariji sin mi je mahnuo mašicama, } \\
\text { ali pošto je megasmrad kao i svi naši } \\
\text { zur anderen Seite, ... (75) }\end{array}$ \\
\hline $\begin{array}{l}\text { 26) Mitten in den Sommeram skrenuo pogled na drugu } \\
\text { seburtstag, und da solle }\end{array}$ \\
$\begin{array}{l}\text { stattfinden. (57) } \\
\text { stratte Tatjana }\end{array}$ & $\begin{array}{l}\text { 'Ona je imala rođendan usred letnjeg } \\
\text { raspusta i tada je trebalo da bude mega- } \\
\text { žurka. (58) }\end{array}$ \\
\hline
\end{tabular}

${ }^{12}$ Дуденов речник бележи четири семеме префиксоида Riesen-: Riesen- (ugs. emotional verstärkend): 1. drückt in Bildungen mit Substantiven aus, dass etw. einen besonders großen Umfang, eine besonders weite Ausdehnung hat: Riesenhaus, -plakat, -tasche; 2. drückt in Bildungen mit Substantiven aus, dass etw. eine besonders große Anzahl, Menge, ein besonders hohes Ausmaß hat: Riesenauflage, -auswahl, -defizit, -umsatz; 3. drückt in Bildungen mit Substantiven aus, dass etw. von großer Intensität ist: Riesendurst, -enttäuschung, -überraschung; 4. drückt in Bildungen mit Substantiven aus, dass jmd. oder etw. als ausgezeichnet, hervorragend angesehen wird: Riesenfußballer, -spiel, -witz. (Дуден 2006) 
Семантичка веза између префиксоида и слободне морфеме јасно је видљива у примеру 27), док се примерима 28) и 29) потврђује значење 'екстремна вредност, интензитет' овог префиксоида. Упореди:

\begin{tabular}{|l|l|}
\hline $\begin{array}{l}\text { 27) Und irgendwo sind garantiert auch Rie- } \\
\text { seninsekten da oben. }(120-121)\end{array}$ & $\begin{array}{l}\text { 'A negde gore garant postoje one dži- } \\
\text { novske bube. }(120-121)\end{array}$ \\
\hline $\begin{array}{l}\text { 28) ..., und dann sahen wir schon das Haus. } \\
\text { Rot geklinkert, ein Vorgarten voller Fahrräder, } \\
\text { vom See her ein Riesengeschrei. (91) }\end{array}$ & $\begin{array}{l}\text {..., a onda smo videli kuću od crvene } \\
\text { cigle, sa baštom punom bicikala, dok je } \\
\text { sa jezera dopirala užasna buka. (91) }\end{array}$ \\
\hline $\begin{array}{l}\text { 29) ..., und wenn es nicht leuchtet, ist das jedes } \\
\text { Mal eine Riesenenttäuschung. (67) }\end{array}$ & $\begin{array}{l}\text {..., ali ako ne zasvetli, uvek je užasno } \\
\text { razočaranje. (67) }\end{array}$ \\
\hline
\end{tabular}

4.2.3. На крају овог поглавља остаје да закључимо да елативни префискоид mеga- у немачком језику за апсолутне синониме има деноминалне префискоиде end- и riesen-, а њихова међусобна заменљивост условљена је дистрибутивним ограничењима која наведени немачки префиксоиди показују. Са друге стране, српски језик не познаје префиксоиде домаћег порекла, те се у сва три случаја као еквивалент јавља страни префиксоид мега-, који у ТК са адјективском базом остварује значење 'екстремна вредност, интензитет', као што је то и у немачком језику случај, док у ТК са именичком основом може остварити сва значења полисемног префиксоида riesen-, који је у немачком језику увек заменљив префиксоидом теga-.

4.3. НЕмАчки ПРЕФиксоиди. Поред већ наведених, у нашем корпусу потврђени су и други деноминални префиксоиди немачког језика са аугментативним значењем, нпр. stock-, knall-, tod- и höllen-, као и пејоративни префиксоид scheiß-. Сви они, како наводе Флајшер и Барц (1995: 231), почивају на поређењу (нпр. stocksteif = steif wie ein Stock), које се у неким случајевима може само посредно парафразирати, тј. метафорички објаснити (нпр. brand-: brandeilig = so eilig, wie man es bei einem Brand hat; brandneu, brandaktuell = brennend aktuell; tod-: todsicher = so sicher wie der Tod). Осим деноминалних, у нашем корпусу потврђен је и девербативни префиксоид stink-, као и деадјективски префиксоид voll-. Међутим, услед непостојања формалног домаћег еквивалента (кореспондента) у српском језику, приликом њиховог превођења прибегава се различитим средствима за изражавање денотативног и конотативног значења: префиксацији (30), употреби градуативних партикула, прилога или придева $(31,32,33)$, транспозицији (34) као и остваривању само денотативне еквиваленције (35). Упореди: 


\begin{tabular}{|l|l|}
\hline $\begin{array}{l}\text { 30) Sie stieg nur mit Shorts und einem knal- } \\
\text { lengen Pullover aus dem Auto, ... (70) }\end{array}$ & $\begin{array}{l}\text { 'Izašla je iz automobila, samo u šortsu i } \\
\text { pretesnom džemperu, ... (71) }\end{array}$ \\
\hline $\begin{array}{l}\text { 31) Ganz ausgemergelt, aber auch irgendwie } \\
\text { vollfit. (128) }\end{array}$ & $\begin{array}{l}\text { 'Sasvim istrošeno, ali istovremeno neka- } \\
\text { ko veoma zdravo. (128) }\end{array}$ \\
\hline $\begin{array}{l}\text { 32) ..., es würde mich todunglücklich machen, } \\
\text {... (61) }\end{array}$ & '..., jer bih bila užasno nesrećna ... (62) \\
\hline $\begin{array}{l}\text { 33) Es machte einen Höllenkrach. (161) } \\
\text { 34) „Es ist stockfinster. Keiner sieht uns.”, } \\
\text { (161) }\end{array}$ & $\begin{array}{l}\text { '... uračnaklenu buku. (161) } \\
\text { vidi.” (160) }\end{array}$ \\
\hline $\begin{array}{l}\text { 35) Und zweitens, was die Leute denken, ist } \\
\text { scheißegal. (28) }\end{array}$ & $\begin{array}{l}\text { 'Kao drugo, svejedno je šta drugi misle. } \\
(30)\end{array}$ \\
\hline
\end{tabular}

Детаљнија анализа ТК са немачким префиксоидима, међутим, превазилази оквире овог истраживања, у чијем фокусу се пре свега налазе префиксоиди страног порекла потврђени у једном од језика који се пореде и њихови еквиваленти у другом језику.

4.4. ПРЕФИКСОИДИ ULTRA-/УЛтPA- и GIGA-/ГИГА-? Примери Потврђени на форумима оба језика указују на спорадичну самосталну (придевску или прилошку) употребу елативних морфема ultra- / ултра- и giga- / гuга-, пре свега у говору младих, новокомпонованим турбо-фолк песмама и сл., што илуструју следећи примери:

36) Oder wie mein (Katrin) Opa sagen würde: Es war GIGA :-) Vielen Herzlichen Dank für alles! (www.will-marry.de/kundenstimmen.html; 20.4.2017.)

37) Kaum richtig im Wasser, fingen alle an zu schreien. Waaaaah, das war ultra!

(https://twoontourdotcom.wordpress.com; 26.1.2018.)

Међутим, у нашем корпусу немачког језика потврђен је само један пример са творбеном морфемом ultra-, који у српском није преведен истим творбеним обрасцем (38), али га не треба сматрати искљученим (нпр. ултраслатка), док за giga- / гига- не налазимо потврде. Упореди:

\begin{tabular}{|l|l}
\hline 38$)$ Und die ultrasüße Jennifer. (78) & 'I ekstra riba Dženifer. (77)
\end{tabular}


Са друге стране, морфема hyper- / хипер- не показује тенденцију као осамостаљењу. Разлог томе могао би се наћи у објашњењу аутора Флајшер и Барц (1995: 204-205) да се hyper- (griech. über) употребљава пре свега за емоционално наглашено негативно вредновање (нпр. Hyperkultur, Hyperkritik), за разлику од super- (lat. über), којим се обично изражава емоционално наглашено позитивно вредновање (нпр. Superschmuck, Superpreis, Superbadeort).

Остаје да се прати овај процес, те утврди да ли ће за сада само спорадично потврђени примери из нижих језичких супстандарда наћи ширу употребу у РФС.

5. ЗАКључАк. На основу спроведене анализе може се извести закључак да је творбени модел деривације уз помоћ префиксоида (страног и домаћег порекла) у функцији семантичке модификације основе (придева или именице) веома продуктиван у немачком језику, док је у српском потврђен само са префиксоидима страног порекла, будући да српски језик не познаје домаће префиксоиде. Ипак, супротно постојећој литератури, која обично говори само о назнакама овог процеса, анализа је показала да је инвентар префиксоида у српском језику већи него што се то очекивало (потврђени су префиксоиди супер-, екстра- и мега-), што је последица осамостаљивања елативних префикса страног порекла, пре свега у РФС, те њихова све чешћа придевска одн. прилошка употреба. На тај начин објашњава се и прелазак ових морфема из класе префикса у класу префиксоида, што за резултат има наглашену хомонимију префискоид vs. придев / прилог / именица / конфикс.

Творбени образац префиксоид + придев / именица стилски је маркиран као разговорни, а ТК овог типа спадају у емоционално-експресивну лексику, у којој су елативни префиксоиди носиоци конотативне (позитивне или негативне) семантике.

У нашем корпусу најдоминантнији су примери са префиксоидом super-/ суnер-, док се у српском запажа далеко чешћа самостална реализација морфеме екстра у односу на немачки језик. Префиксоид теga-у корпусу немачког језика није фреквентан, већ се на његовом месту обично јављају немачки истозначни деноминални префиксоиди end- и riesen-, док се у српском разговорном језику запажа све чешћа употреба морфеме мега-, како у ТК, тако и у самосталној реализацији. Са друге стране, статус морфема ultra- / ултра- и giga- / гига- још увек није јасно дефинисан, мада назнаке њиховог осамостаљивања постоје, док hyper- / хипер- и даље треба интерпретирати као префикс. 


\section{ИЗВОРИ}

Herrndorf, Wolfgang. Tschick. Roman. 5. Auflage. Berlin: Rowohlt Taschenbuch Verlag, April 2012.

Herndorf, Volfgang. Čik. Roman. Beograd: Laguna, 2012. Prevela s nemačkog Mirjana V. Popović.

\section{ЛИТЕРАТУРА}

Ајзенберг 2006: P. Eisenberg, Grundriss der deutschen Grammatik, Band 1: Das Wort, 3., überarbeitete und aktualisierte Auflage, Stuttgart / Weimar: J.B. Metzler.

Алановић и др. 2014: M. Alanović, A. Đurović, U. Engel, S. Srdić, Deutschserbische kontrastive Grammatik, Teil II: Das Nomen und der Nominalbereich, München / Berlin: Verlag Otto Sagner.

Алтман и Кемерлинг 2000: H. Altmann, S. Kemmerling, Wortbildung fürs Examen. Studien- und Arbeitsbuch, Linguistik fürs Examen, Band 2, Wiesbaden: Westdeutscher Verlag.

Дуден 2006: Duden - Deutsches Universalwörterbuch, 6. Auflage, Mannheim [CD-ROM].

Доналис 2005: E. Donalis, Die Wortbildung des Deutschen. Ein Überblick, 2., überarbeitete Auflage, Tübingen: Gunter Narr Verlag.

Елзен 2005: H. Elsen, Deutsche Konfixe, Deutsche Sprache: Zeitschrift für Theorie, Praxis, Dokumentation, 33, 133-140.

Елзен 2009: H. Elsen, Affixoide: Nur was benannt wird, kann auch verstanden werden, Deutsche Sprache: Zeitschrift für Theorie, Praxis, Dokumentation, 37, 316-333.

Елзен 2011: H. Elsen, Neologismen. Formen und Funktionen neuer Wörter in verschiedenen Varietäten des Deutschen, 2., überarbeitete Auflage, Tübingen.

Енгел и Мразовић 1986: U. Engel, P. Mrazović (Hrsg.), Kontrastive Grammatik deutsch-serbokroatisch, Prvi tom, Novi Sad: Institut za strane jezike i književnosti.

Катнић-Бакаршић 1999: M. Katnić-Bakaršić, Lingvistička stilistika, Research Support Scheme. $<\mathrm{http}: / /$ rss.archives.ceu.hu/archive/00001017/01/18. pdf> 19.09.2016. 
Клајн 2002: И. Клајн, Творба речи у савременом српском језику, Први део: Слагање и префиксаиија, Београд.

Колер 2011: W. Koller, Einführung in die Übersetzungswissenschaft, 8. Auflage, A. Francke UTB.

Моч 1999: W. Motsch, Deutsche Wortbildung in Grundzügen, Berlin: Walter de Gruyter.

Петронијевић 2005: Б. Петронијевић, Статус афиксоида у типологији творбених морфема, Наука и образовање, књ. 6, том I, Бања Лука, 193-206.

ПСЈ 2011: М. Пешикан, Ј. Јерковић, М. Пижурица, Правопис српскога језика, Друго издање, Нови Сад: Матица српска.

Сатмари 2011: P. Szatmari, Affixoide - Pro und Kontra, Szendi, Zoltán / Backes, Johanna (Hrsg.): Jahrbuch der ungarischen Linguistik, Budapest, 156-176.

Станојчић и Поповић 2004: Ж. Станојчић, Љ. Поповић, Граматика српског језика, Уџбеник за I, II, III и IV разред средње школе, Београд: Завод за уџбенике и наставна средства.

Тошовић 2002: В. Tošović, Funkcionalni stilovi (Funktionale Stile), Institut für Slawistik der Karl-Franzens-Universität Graz.

hopић 2008: Б. Ћорић, Творба именица у српском језику, Библиотека Књижевност и језик, књига 24, Београд: Друштво за српски језик и књижевност Србије.

Флајшер и Барц 1995: W. Fleischer, I. Barz, Wortbildung der deutschen Gegenwartssprache, 2., durchgelesene und ergänzte Auflage, Tübingen: Max Niemeyer Verlag.

Шмит 1987: G. D. Schmidt, Das Affixoid. Zur Notwendigkeit und Brauchbarkeit eines beliebten Zwischenbegriffs der Wortbildung, Deutsche Lehnwortbildung. Beiträge zur Erforschung der Wortbildung mit entlehnten WB-Einheiten im Deutschen, Tübingen: Narr, 53-101. 


\section{PRÄFIXOIDE ALS CHARAKTERISTIK DER ALLTÄGLICHEN KOMMUNIKATION AM BEISPIEL DES ROMANS TSCHICK VON WOLFGANG HERRNDORF UND SEINER ÜBERSETZUNG INS SERBISCHE}

\section{Zusammenfassung}

In der vorliegenden Arbeit wird am Beispiel des Romans Tschick von Wolfgang Herrndorf und seiner Übersetzung ins Serbische der Gebrauch von Präfixoiden in der deutschen Alltagssprache, vor allem in der Jugendsprache, analysiert und mit der serbischen Sprache verglichen, wo dieses Wortbildungsmuster üblicherweise als Randerscheinung betrachtet wird, da das Serbische, im Unterschied zum Deutschen, keine „,heimischen” Präfixoide kennt. Im Fokus dieser Arbeit stehen vor allem die elativen Präfixoide lateinischer und griechischer Herkunft (super-, extra-, mega-), die auf Grund ihres immer häufigeren Gebrauchs als selbstständige Lexeme (Adjektive / Adverbien) in der Alltagssprache aus der Klasse der Präfixe in die der Präfixoide übergetreten sind, wobei sie zur stilistischen Markierung, emotionaler Verstärkung und Expressivität der entstandenen Derivate beitragen. Darüber hinaus werden auch die gleichbedeutenden Präfixoide deutscher Herkunft in Berücksichtigung genommen (end- und riesig-), sofern sie das fremdsprachige Äquivalent (mega-) im Serbischen haben. Die Arbeit beschäftigt sich weiter mit der Möglichkeit, die formale, denotative und konnotative Äquivalenz zwischen der Ausgangsprache und der Zielsprache zu erzielen, in Anbetracht dessen, dass im Deutschen, im Unterschied zum Serbischen, das genannte Wortbildungsmodell äußerst produktiv ist. Die Analyse hat gezeigt, dass die Tendenz zum selbstständigen Gebrauch der oben genannten, einst nur gebundenen Morpheme in der Alltagssprache (Jugendsprache) stark vertreten ist. Im Gegensatz dazu lässt sich diese Tendenz bei den gleichbedeutenden Morphemen ultra- und giga-nur in Ansätzen erkennen, während das Morphem hyper- immer noch als nur gebunden erscheint.

Schlüsselwörter: Präfix, Präfixoid, Alltagssprache, Deutsch, Serbisch, Äquivalenz. 